\title{
Conceptualising the management of packaging within new product development:
}

A grounded investigation in the UK fast moving consumer goods industry

\begin{abstract}
$\underline{\text { Abstract }}$
Purpose- The purpose of this study is to: (i) contribute to existing models of new product development (NPD), and provide new understanding of how a new product's packaging is managed and integrated into the NPD process of fast moving consumer goods firms; and (ii) build on prior research suggesting that firms lack a pipeline of new packaging innovations by uncovering the factors that influence this pipeline issue.
\end{abstract}

Design/methodology/approach- A grounded theory methodology was adopted. Research was conducted through a total of thirty-seven interviews with key informants in the UK FMCG industry, packaging industry, and associated firms.

Findings- Three distinct levels of packaging development were revealed: skin deep, body modification, and format change. The emphasis within many firms is primarily on changes to packaging at the level of the label (skin deep) or aesthetic design (body modification), whilst technological and format changes are overlooked. The factors that contribute to the level at which development is undertaken are identified.

Implications- Existing literature has largely examined packaging at the level of skin deep and body modification. The development of new packaging technology has been overlooked. Our propositions guide the way forward for further research. For firms, the development of new formats and genuine packaging innovation may be being overlooked. There is a need for them to re-examine their activities to ensure that they are addressing all three levels.

Originality/value- This theory building study has generated a new typology which, alongside the unique framework, reveals the factors influencing the level of emphasis within firms.

Keywords- Packaging, new product development, absorptive capacity, FMCG, food and drinks.

Article classification- Research paper. 


\title{
Conceptualising the management of packaging within new product development:
}

A grounded investigation in the UK fast moving consumer goods industry

\begin{abstract}
$\underline{\text { Abstract }}$
Purpose- The purpose of this study is to: (i) contribute to existing models of new product development (NPD), and provide new understanding of how a new product's packaging is managed and integrated into the NPD process of fast moving consumer goods firms; and (ii) build on prior research suggesting that firms lack a pipeline of new packaging innovations by uncovering the factors that influence this pipeline issue.
\end{abstract}

Design/methodology/approach- A grounded theory methodology was adopted. Research was conducted through a total of thirty-seven interviews with key informants in the UK FMCG industry, packaging industry, and associated firms.

Findings- Three distinct levels of packaging development were revealed: skin deep, body modification, and format change. The emphasis within many firms is primarily on changes to packaging at the level of the label (skin deep) or aesthetic design (body modification), whilst technological and format changes are overlooked. The factors that contribute to the level at which development is undertaken are identified.

Implications- Existing literature has largely examined packaging at the level of skin deep and body modification. The development of new packaging technology has been overlooked. Our propositions guide the way forward for further research. For firms, the development of new formats and genuine packaging innovation may be being overlooked. There is a need for them to re-examine their activities to ensure that they are addressing all three levels.

Originality/value- This theory building study has generated a new typology which, alongside the unique framework, reveals the factors influencing the level of emphasis within firms.

Keywords- Packaging, new product development, absorptive capacity, FMCG, food and drinks.

Article classification- Research paper. 


\section{Introduction}

An increasing number of companies are exploiting packaging as a method of differentiating and improving the performance of their products within the highly competitive fast moving consumer goods (FMCG) industry (Mahalik and Nambiara, 2010). Consequently, it has been suggested that packaging is a 'priority issue' within NPD (Koss, 2007, p. 132). A number of factors have contributed to this growing significance of packaging processes: (i) government and consumers' concerns of the impact of packaging on the environment (Rundh, 2005); (ii) increased logistics costs (Rundh, 2005); and (iii) the expanding competition from retailer brands (Vazquez et al., 2003). Packaging has received relatively little attention in mainstream marketing media (Saghir, 2002; Rundh, 2005) and theory in this area is lacking (Simms and Trott, 2010). Our research is the first empirical study to investigate firms' management of packaging within their NPD activities. This study seeks to make a theoretical contribution by providing a new and unique multiple-perspective on the management of packaging. The results lead to the generation of a new theoretical conceptualisation through which we can view packaging development, resulting in deeper and more meaningful insights.

The first major aim of this study is to gain new understanding of the integration of packaging into the NPD process of FMCG firms. Our analysis of the literature reveals a major weakness in the existing models of NPD (e.g. Anselmsson and Johansson, 2009; Francis et al., 2008). Each fails to provide us with an understanding of the management of this critical and integral part of the product offering (e.g. Silayoi and Speece, 2004; Simms and Trott, 2010) beyond the development of label reprographics. Our findings build on existing models of NPD packaging development and provide new insights beyond this superficial level. The second major aim of this study is to investigate how firms manage the development of new packaging. To this end, we build on research by Ahmed et al. (2005), which revealed that firms frequently fail to create a pipeline of new packaging ideas and concepts (Ahmed et al., 2005). This study reveals a number of interrelated factors that may preclude firms from developing an effective pipeline of new packaging concepts and in so doing identifies important implications of theoretical and practical interest.

The results of this paper provide a unique contribution to theory by bringing the innovation management, $R \& D$, and NPD literature to bear on this topic that has traditionally been the domain of marketing. This multiple perspective provides insight into the management of packaging within NPD. In particular, we develop a typology of packaging 'penetration', which illustrates different 'levels' of packaging activities within firms. Identification of these discrete levels provides new insights beyond the aesthetic level at which prior research in marketing has focused. The study's findings indicate that the emphasis within firms is 
primarily at the level of the label and basic aesthetic design changes, while attention has rarely reached the level of physical technological development. Our typology contributes to a wider framework that captures the factors that influence the specific 'level' of a firms packaging activities. We show that limited absorptive capacity and insufficient 'packaging champions' can lead to an emphasis on skin deep and aesthetic modifications to the exterior body of packaging within NPD. Our findings demonstrate that technological packaging innovation is often overlooked.

The remainder of this paper is structured as follows. Firstly, we provide an overview of the literature on product development and packaging in line with the grounded interpretive approach adopted within our study. This section begins with a brief review of theoretical and empirical work on NPD, with the emphasis being on the FMCG industry and food and drinks sectors. The discussion identifies the weaknesses of existing conceptualisations and the need for a new approach. This is followed by an exploration of the role of packaging within NPD. The second section of the paper details the methodology. After this the findings and analysis of the grounded investigation are presented. Finally, the limitations of the article are discussed as well as conclusions and possible directions for future research.

\section{Literature Review}

Despite the integral nature of packaging to the product offering and assertions that product and packaging should be considered holistically during NPD (Ahmed et al., 2005; Simms and Trott, 2010), packaging and NPD research has proceeded along fairly independent tracks to date. In the following literature review we discuss aspects that pertain to the current study of packaging development and reveal the need for a new theoretical approach to conceptualizing the management of packaging in NPD.

\section{Weaknesses of Existing Conceptualisations of NPD in the FMCG Industry}

The majority of existing NPD studies have focused on technology-intensive industries (Lager, 2000; Francis et al., 2008). Existing models characterise NPD according to the discrete activities undertaken (i.e. stage based models, e.g. Cooper, 2008), simultaneous and crossfunctional nature of activities (e.g. MacGregor et al., 2006), and external network inputs (e.g. Berkhout et al., 2011).

Appendix 1 summarises key NPD models in the FMCG industry and the food and drinks sectors. Only two empirical studies have provided any real insight into the management of 
NPD within the FMCG industry ${ }^{1}$ : Ernst and Young (1999), a consultancy led project involving AC Nielsen and the Product Development Management Association (PDMA), and Francis et al.'s $\left(2008^{2}\right)$. Both fail to provide specific insights into the management of packaging development beyond the design of graphics and artwork.

A review of the literature also reveals an additional shortcoming in the existing models within the FMCG industry; each adopts an activity-based conceptualisation of NPD. Although these models are well established within the innovation and NPD literature (e.g. Kleinschmidt \& Cooper, 1991; Troy et al., 2006), driven by their practical ability to improve the performance of NPD (e.g. Pattikawa et al., 2006; Oorschot et al., 2010), these activity-based conceptualisations have been criticised often (Balconi, 2010). It is not within the remit of this article to provide a complete account of these criticisms (for more information see McCarthy et al., 2006; Berkhout et al., 2011). In the context of this study, we identify two critical weaknesses, resulting from their inability to capture: the nature of NPD as a result of the emphasis on modelling the process/stages, and the organisational and industry context in which development is taking place. These are addressed in the following sections.

\section{The Need for a New Approach to Conceptualising Product and Packaging Development}

A major shortcoming of activity-based models is their failure to capture the simultaneous and overlapping nature of activities (see Fuller, 2004) and external network interactions (see Berkhout et al., 2011). As a result, it has been suggested that these models do not provide an adequate conceptualisation of NPD in reality, nor reveal factors that lead innovations to come about (Berkhout et al., 2011). Within the broader literature, network and cross-functional models have provided important contributions to our understanding. Within the food sector however, only a few studies involving single project cases exist (e.g. Huston and Sakkab, 2006).

Existing activity-based models fail to capture important inputs; this represents a significant limitation in two respects. Firstly, there is a failure to account for the retailers' involvement (Stewart-Knox and Mitchell, 2003) and their specific needs within NPD (Corstjens and Corstjens, 1995). This is a significant omission as retailers have an important influence on development activities. The successful marketing of branded FMCG products depends on

\footnotetext{
1 The FMCG Industry consists of three sectors: food, drinks, and household goods (KeyNote, 2006)

2 Table I focuses on research by Francis et al. (2008), which we consider to be the most in-depth and detailed project, although other studies have been undertaken (e.g. Francis, 2006)
} 
satisfying their needs (Corstjens and Corstjens, 1995). Indeed, this is particularly pertinent to packaging due to its influence on the display and handling of the product (e.g. Mulhern, 1997). The second limitation is the failure to capture the suppliers' involvement and collaboration. Supplier relationships have received particular attention within the innovation and NPD literature (see Wynstra et al., 2010), and their role within food product and packaging development has been recognised (Fuller, 2004). The incorporation of outside agencies and external technical expertise have been found to enhance NPD (Costa et al., 2001; Stewart-Knox and Mitchell, 2003). Furthermore, packaging suppliers have become increasingly important within NPD in the FMCG industry (Key Note, Food Industry; 2005; 2010). The innovation literature, however, highlights that the potential for suppliers to contribute to the customer's $R \& D$ is dependant upon the customer maintaining internal knowledge capabilities in order for the value of new technologies to be recognised internally (Yeoh, 2009). Yet prior research within the FMCG industry provides little insight into the extent to which packaging suppliers contribute to the NPD activities of firms. We therefore advocate a new theoretical approach to conceptualising product and packaging development.

\section{Characterising Product Development in FMCG}

We now turn to the organisational and industrial context in which NPD is taking place. Empirical studies of product success and failure within the food and drinks sectors have revealed notable product failure rates and restricted chances of new product success (Rudder et al. 2001). These are costly to the industry (Morris, 1993). Whilst there is a lack of consensus on the causes of this (for full review see Stewart-Knox and Mitchell, 2003; Fuller, 2004), two factors seem to be of particular importance: inefficiencies in the NPD process itself, and the lack of a formal process (Rudolph, 1995; Rudder et al., 2001). Given the lack of empirical research into the management of packaging development it remains unclear as to how these issues impact the development of packaging. Some organisations have focused on re-developing old products (to create new products) in an attempt to increase success rates (Iiori et al., 2001). This approach, however, perpetuates failure (Stewart-Knox and Mitchell, 2003) and has resulted in a low number of innovative products being launched (Rudolph, 1995), which may have led to the characterisation of product development within FMCG as risk averse and short-term orientated (Ahmadi and Wang, 1999). Given the importance of packaging to FMCG products and their success (see following section IV), the integration of packaging development into NPD could provide considerable opportunities to improve performance in these areas. This further informs the rationale for our study.

The final factor that warrants attention is the characteristics of this mature process industry, which prior studies within the FMCG industry have failed to address. Francis et al. (2008) 
characterises the industry as high volume, multi product, and high variety NPD. Furthermore, an orientation toward cost minimisation is particularly apparent in this type of industry where price-based competition is high (see Utterback and Abbernathy's innovation lifecycle, 1975). This results in an emphasis on minimising costs and improving production efficiency within NPD. The cost implications of adopting new technologies therefore become significant; high capital costs, development costs, and switching costs (Bunduchi and Smart, 2010) can prevent progression. A combination of these factors can also lead to an environment in which incremental and exploitative innovation dominate over long term and substantial technological changes (e.g. Benner and Tushman, 2002; Chu et al., 2009).

\section{Marketing and Packaging Management: Packaging's Relevance to NPD}

Packaging has received broad and dispersed coverage within the marketing literature as a result of its extension across the boundaries of a number of marketing disciplines (Ahmed, 2005; Simms and Trott, 2010). Whilst packaging is an integral part of the product offering that can effectively become the product in the eyes of the consumer (Silayoi and Speece, 2004), existing literature has failed to conceptualise the management of packaging within NPD. Recently the pertinence of developing new theory in this area has been identified (Simms and Trott, 2010) and a key role of packaging in product development and the creation of innovative opportunities has been identified (Ahmed, 2005; Koss, 2007). Within the development of new FMCG products the development of packaging forms an important part of the process. Consumers use packaging (alongside other cues, such as price and the brand) to form perceptions of a product (Ampuero and Vila, 2006; Orth and Malkewitz, 2008). Indeed, Deliza and MacFie (2001) note that in the case of some new products the consumer will have little or no other information from which they can draw inferences and form perceptions.

\section{INSERT TABLE I}

In the context of the integral relationship between the product and its packaging, Table I builds and expands upon prior articles to provide a more comprehensive understanding of the functions that packaging performs for the product. This reveals its relevance to many NPD decisions (Koss, 2007). Simms and Trott (2010) and Ahmed et al. (2005) argue that it is necessary to consider the product and packaging concurrently and holistically within the NPD process. Yet, despite these assertions, Ahmed et al. (2005: p. 762) revealed that:

“... packaging is critical component of one's marketing mix,... one needs to have a pipeline of packaging ideas and concepts in development, but many brands do not have such type of system in place." 
The emphasis on cost-saving designs can lead to limited new packaging demand side progression and margin erosion (Richmond, 2004). This cost emphasis is of particular concern given that Fuller (2004; p. 88, citing Dean, 1974) highlights that it is "like looking for the leak in the bottom of my canoe as I drift towards an unseen waterfall". Yet, the preceding discussions have identified a lack of empirical research in this domain. This further reinforces the need for a new theoretical approach that develops our understanding beyond the superficial insights provided in prior studies. This study argues that insights uncovered within the existing NPD, innovation, and R\&D literature provide a foundation for improved conceptualisation of new packaging development within FMCG firms.

\section{Methodology}

We adopted a grounded and interpretive approach for the purposes of explorative richness and as a result of the lack of nascent packaging theory. This approach effectively provides a 'voice' from those involved (Nag et al., 2010). The study employed a qualitative interview approach using selected managers with expert knowledge in this area as 'key informants' (Churchill et al., 2005). We recorded and analysed the experiences of key decision makers involved in the management of packaging development from within FMCG firms themselves and the supply chain. This data provided insights and 'grounded events' that influence the operation of NPD processes.

The methods employed for this study followed the guidelines for theory development in marketing (Deshpande, 1983). As little theoretical insight existed for deductive enquiry, a grounded interpretive approach was adopted to encourage explorative richness (Nag et al., 2007). The "interpretivist" nature of the research was consistent with the aims of better describing, understanding, and explaining the key influences and processes involved in packaging for NPD. This approach contrasts with a hypothetico-deductive approach, in which a priori theory is tested against empirical data (Keaveney, 1995). Grounded theory is also well suited to theory generation and is associated with actions and processes (Strauss and Corbin, 1998). This approach is therefore relevant to this study as the incorporation of packaging into the NPD process can be considered a basic social process that is influenced by basic structural conditions. Hence, the approach was well suited due to the lack of insight in the existing literature creating a need for the development of theory.

\section{Sampling and Data Collection}

Thirty-seven 'key informants' were interviewed (Churchill et al., 2005) over a twelve-month period. Interviewees were selected using the principle of theoretical or purposive sampling, which is inextricably intertwined with data collection and the emergent theory (Strauss and 
Corbin, 1998). The interview process was reflexive in nature and data collection and analysis were intimately linked (Goulding, 2002).

In order to gain multiple perspectives on the management of packaging interviews were conducted across five firm types, which can be categorised into three different groups (Appendix 2):

1. FMCG own brand retailers (R1-7) and FMCG brand owners/product manufacturers (P8-12);

2. Specialist packaging design and marketing consultancy firms (C13-22);

3. Packaging manufacturers (M27-37) and industry body representatives (I23-26).

Participants included senior managers, technologists, consultants, and directors from each of the firm types. All individuals interviewed were decision makers or heavily involved in packaging planning or development within their respective organisational type. The incorporation of this variety of interviewees was in order to capture the 'population' of those involved in the development of packaging across the supply chain, and reflects the outsourced nature of the packaging development process. Furthermore, this combination of interviewees enabled the capture of multiple perspectives on the management of packaging (Nag et al., 2007). An expert sample was employed to select the interviewees for in-depth investigation and to reach specialised populations (Neuman, 2003). Although the sample size appears small, this research aimed to provide preliminary insights based on the expertise of the participants (Denzin and Lincoln, 1994).

The length of the interviews varied from forty-five to one hundred and twenty minutes. Questions involved areas such as perceptions of packaging and its development, the role of packaging within the firm, the delegation of responsibility within the firm, and the use of external supply chain partners in the development process. Research team members with high inter-rater reliability scores were involved in the research process (Miles and Huberman, 1994). Each held a PhD in management research. The team followed a set interviewing procedure including noting key points, asking additional probing questions, and reflecting on their notes.

Data was collected using a semi-structured interview guide in order to gain accurate perspectives of informants' opinions and so that the research topics could be sufficiently explored (Daymon and Holloway, 2004). Interview questions were drafted in order to investigate the development of packaging in general and to facilitate understanding of management perceptions towards its role within NPD. Interviews also examined consumer 
and technical input during packaging development, where responsibility for development is external. Interviews were transcribed immediately after their conclusion and transcripts were thoroughly examined and coded on a line-by-line basis (open coding) before grouping in categories (axial coding) (Strauss, 1987).

\section{Analytical Procedure}

Data analysis was conducted according to the naturalistic enquiry guidelines of Lincoln and Guba (1985) and the techniques of constant comparison (Strauss and Corbin, 1998). This ensured a rigorous process for the collection and analysis of the data, and allowed identification of delineating themes and aggregate dimensions (Isabella, 1990). Data analysis was performed using a three-step content analysis procedure (Miles and Huberman, 1994). In the first phase, transcripts were broken down into first order codes ranging from a phrase to several sentences. The second phase involved organisation and grouping of the first order codes into emergent categories. A full content analysis was then undertaken in order to resolve any disagreements among researchers. The final phase of analysis involved classification of categories into themes, which summarised core unifying observations (Strauss and Corbin, 1998).

The use of multiple researchers who continually communicated about methodological decisions was employed (e.g. LeCompte and Goetz, 1982). Each member of the team reviewed each others transcripts to ensure consistency in the analysis of the interviews. Research assistants also reviewed the transcripts, parts of the data analysis and the final report (Yin, 1994). Where necessary clarifications were made (Yin, 1994). Patterns that emerged from the data were analysed and compared with existing studies (Strauss and Corbin, 1998). The focus of this analysis therefore was on discovery rather than refinement.

\section{Emergent Findings}

The patterns that were observed across the interviews allowed inferences to be drawn regarding the factors that characterise management of packaging within NPD. Commonalities were observed in the factors involved in packaging's management within the NPD process and those influencing a firm's pipeline of new developments. The emergent data structure was initially organised into fifteen first order categories, which were subsequently assembled into nine second order themes and three overarching dimensions. Figure 1 presents the framework developed from the analysis of these dimensions, and provides a dynamic view of how these factors work in motion. 
In the sections that follow, we present our analysis of the findings, beginning with the presentation of our framework that builds a new understanding of the factors influencing the level at which firms' packaging development activities focus. Our framework conceptualises the management of packaging and acts as a tool to understand how the management of NPD influences the type of packaging activities undertaken, and the outputs that result from the process. A classification of three types or levels of packaging change that result from the NPD of FMCG firms is then presented. This is followed by a more detailed discussion abour the factors identified within the framework. Within this discussion eight propositions are developed. These guide the way forward for future research.

\section{Analysis}

I) Conceptualising the Management of Packaging within NPD: A Grounded Framework of Packaging's Management

The management of packaging was characterised as risk averse and ad hoc. Managers frequently had a myopic and skewed view of packaging, this included an emphasis on costs and packaging's role as a simple vehicle to hold graphic design and marketing communications messages. This limited supplier cooperation. Figure 1 provides a synthesis of our findings. The inductively-developed framework draws on: (i) the views and perceptions of those involved in the process; (ii) themes that emerged from the study; and (iii) factors identified in previous research. It identifies relationships between the key aspects of the management of packaging and relates this to a typology of packaging penetration. These key relationships are also reflected in the propositions generated by this study (e.g. P1).

The centre of the framework captures the three different levels at which packaging development occurs (these are identified within the typology and discussed in the following section). The four (dashed) boxes placed around this central element display the factors that determine the level at which development occurs: (i) firm factors, (ii) the role and power of the retailer, (iii) the role and power of the consumer, and (iv) the utilisation of external firms and their capabilities. The figure also displays the nature of the relationships between the four factors. In two of the cases it is interactive and in the other two the relationship is one way. The arrow from retailers is shown as dashed because this only applies in brand owner packaging development, and not for retailer own brand. These key aspects of the framework, reflected in the propositions, will be discussed in the sections that follow.

\section{INSERT FIGURE 1}




\section{II) Classification of Packaging Change: Typology of Packaging Penetration Properties}

The findings uncovered that FMCG firms' management of packaging is at one of three levels, which we classify as skin deep, body modification, and format change/innovation (Table II). Skin-deep packaging changes have the least penetration change. Some firms consider this level of change to be a development of new packaging, but it frequently involves little more than alteration of reprographics, such as creating new labels for a can of soup. Body modification packaging changes penetrate further into the product, but do not alter the format (e.g. can, bag, pouch). Here, the emphasis is on changes to the existing format. For example, to make a bag easier to open. Format changes and innovation represent a fundamental change. For example, moving from a can to a pouch or from a polythene bag to a cardboard tube.

\section{INSERT TABLE I}

\section{Characterising the Management of Packaging within FMCG Firms' NPD Activities}

The findings revealed that the primary objective of the NPD process within FMCG firms was the development of the core product. As a consequence it was "possible for a team to effectively pay lip service to packaging" [P10] until late on in the project. During the product's development, packaging was only considered at a superficial level. Consequently optimised product-packaging combinations were not explored. Teams tended to use existing packaging formats and technologies where possible. This was illustrated with an interview with one Marketing Manager [P9], who stated "we buy packaging off the shelf... looking through suppliers brochures".

FMCG firms were risk averse to packaging change and concerned about the potential damage to their brand. Brand and category managers ${ }^{3}$ were particularly risk averse. For example, one design consultant noted that in a "project for xxxxxxx [a brand leading company],.... despite consumer testing showing that the packaging was more popular than the leading brand, they were still unkeen to try the 'risky' new packaging... " [C18]. Indeed, packaging consultancies frequently had to "push clients to adopt... [new packaging] particularly for established products...as they don't want to damage sales or the brand". Hence minor changes received the majority of attention.

Few firms had NPD team members whose role focused on packaging, or packaging departments. Teams of packaging buyers were identified within some firms who were responsible for the procurement of packaging. Consequently within NPD projects packaging

\footnotetext{
${ }^{3}$ In supermarkets category managers have responsibility for a category of products, such as the fresh meat and fish or vegetables category.
} 
decisions often fell between a number of staff and frequently rested with non-packaging specialists. As result there was frequently a lack of long term strategic planning and the exploration of new opportunities was overlooked. This allocation of responsibility also resulted in a narrow or skewed emphasis during decision-making:

- Marketing members "focus on the label" [R6] and something to put their message on;

- Design members emphasised packaging "graphics and aesthetics" [I24];

- Category/product managers frequently took the responsibility for format decisions, but were frequently overwhelmingly focused on the core product;

- NPD and R\&D members concentrated on the core product and related technical issues;

- Buyers were often responsible for contacting packaging suppliers and arranging supplies at minimal cost, and were particularly influential in decision-making.

The critical factors that related to and influenced the management of packaging were categorised into the following key dimensions:

I. The NPD Team: Packaging capacity and the role of packaging champions;

II. Barriers to change: Internal and External Barriers;

III. Role and Incorporation of External Capabilities and Consumers.

The following sections explore the key findings in each of these areas. These discussions reveal the level of attention packaging received within NPD and the scale and scope of this attention.

\section{The NPD Team: Level of Packaging Capability}

Theme 1: NPD Team-Incorporation of 'packaging champions': Our data suggests that within FMCG firms specialist packaging staff were either non-existent, lacked technical expertise (were responsible for design or reprographics) or they were not integrally involved in NPD decision-making (this is reflected in the first aspect of our framework, which consists of three elements). For example, in a few cases packaging design specialists were incorporated into the team, but their lack of technical expertise resulted in a "lack of internal staff focused on the development of packaging and innovation" (P2). Firms did not harbour packaging development projects as there were no team members to 'champion' packaging and drive its development. 
Previous authors have identified the role of 'heavyweights' and 'champions' in NPD (Markham and Griffin, 1998). Our results demonstrate a lack of staff performing this role for packaging (whom we label 'champions') within the NPD team, and results in lack of individuals actively seeking or championing the opportunities that changes could provide. Hence:

Proposition 1: An absence of internal packaging 'champions' will lead to a skin deep or body modification level of development due to the lack of active pursuit of new opportunities for innovation.

The second consequence was the lack of an individual actively facilitating and pursuing opportunities for supplier networking. Consequently suppliers struggled to establish strategic and long-term collaborative relationships. Packaging was not considered as an ongoing business activity.

Theme 2: Level of Packaging Absorptive Capacity-The findings provided evidence of a lack of industrial design packaging capability within FMCG firms. For example, I23 noted that "Few marketing or new product development managers have the skills or knowledge to develop packaging". This impinged technical development. Interviewees revealed the influence of this capability deficit on supplier communications, which were thus restricted to negotiating minor contracts and changes to current packaging. Firms did not consult with packaging suppliers in a meaningful way in order to utilise their technology or innovative capability and therefore exhibited low levels of absorptive capacity (Cohen and Levinthal, 1990). This was also frequently the case where design firms were used. We therefore make the following proposition:

Proposition 2: NPD teams with a low level of absorptive capacity in packaging technology will overlook opportunities for external packaging innovations. This will result in a propensity towards skin deep and body modification developments.

Theme 3: Industrial Design Capability and the Understanding of Packaging Development-

Data suggested that key decision makers and NPD team members attached different meanings to the development of packaging. For example, marketing staff considered packaging development as integral to NPD, but in reality were actually only considering label changes $\left[\mathrm{R} 4, \mathrm{C} 18, \mathrm{C} 20^{4}\right]$. Similarly, whilst design staff considered packaging development as critical, they were actually only considering basic aesthetic and graphic changes [P9, P11, C13 $\left.{ }^{1}\right]$. These results reveal a deep and underlying problem. In such NPD teams there was a lack of

\footnotetext{
4 This was also supported by the results of the interviews with Packaging Manufacturers, Consultants, and Industry bodies.
} 
recognition that packaging changes could extend beyond label (skin deep) and design (body modification) changes. This led to different understandings of packaging 'development', and as a result technical development was inadvertently overlooked. Hence we make the following proposition:

Proposition 3: NPD teams that lack input from industrial packaging specialists will exhibit a myopic understanding of 'packaging development' resulting in the development of innovative new packaging being inadvertently overlooked.

\section{Barriers to Change: Internal and External Barriers}

Theme 4: Perceptions of Flexibility in the Production Process- The sunk capital equipment costs in the production line acted as a barrier to change due to the high associated costs. As a result, innovation was frequently characterised as short-term (primarily process efficiency and unit costs) and incremental. The majority of changes were driven by design and the market with opportunities for significant technical developments and innovations (including format change) being overlooked.

The importance of process change costs and the emphasis on efficiency is not a significant revelation in itself (e.g. Utterback and Abbernathy, 1975; Benner and Tushman, 2002). Indeed, these switching costs and the installed base are issues that commonly impede the adoption of new technologies (Rogers, 1995). However, our research suggests that it is not just the costs themselves, but also the perceived costs that resulted in firms' unwillingness to examine or explore opportunities for technical change. This was evident from an interview with R4, who revealed that "where marketing staff are responsible for developing packaging their ideas are frequently 'shot down' by manufacturing staff concerned with the potential implications on the production line.... [although] frequently no analysis is undertaken to establish the costs involved...". This resulted in supplier collaboration for development being overlooked. We therefore propose that:

Proposition 4: The extent to which the manufacturing process is viewed as a constraint will harm a firms ability to explore opportunities for technical packaging change. This will subsequently lead to an emphasis on incremental changes at a skin deep and body modification level.

Referring back to the second proposition (packaging capability) this issue is of particular concern as prior research has suggested that technical expertise within the firm can help overcome the high capital costs of change, and identify solutions that reduce the investment required (e.g. Teece, et al., 1996; Zott, 2001). 
Theme 5: The Role and Power of the Retailer-The retailer was also found to influence the emphasis of packaging change as a result of their relative power. Prior literature has established the retailers' powerful role (Corstjens and Corstjens, 1995). Our research reveals that as a result of this power NPD managers were cautious of putting forward new packaging ideas due to packaging's impact on the display and handling of the product (e.g. Mulhern, 1997). Private label brand owners were worried that changes "might alter the shelf space or the possible positioning or display of our product". Indeed, they were fearful of upsetting retailers. Minor changes, such as label changes, were therefore seen to carry less risk. The following proposition can be made:

Proposition 5: A high level of concern regarding the impact of packaging change on the retailer and their display of the product will result in firms primarily considering skin deep and body modification levels of change.

Within this theme own brand NPD warrants discussion. The production of own brand products was outsourced to suppliers who undertook the majority of development (e.g. R1-6, M24-29, P8). This was captured in an interview with R1: "the [retailers] focus is on the product, ... [with a] technical manager creating a development brief, and the supplier comes back with a product and standard packaging". Consequently, it was the supplier that made the majority of packaging format decisions.

Suppliers perceived the adoption of new formats primarily benefitted the retailer and tended to avoid change because of the potential investments and unit cost implications (particularly as they operated on low margins). For packaging suppliers this meant that new innovations had to be "pushed on to both the retailers and manufacturers, as the manufacturer will be happy with what they have got and want to keep costs low ..." (P2). In some cases suppliers would only consider changing the packaging if the retailer threatened to switch to a new supplier.

Theme 6: Role of Powerful Packaging Buyers- In a number of FMCG firms [particularly R1, R3, R6, P7], buyers played an influential role in decision-making. The NPD team would frequently specify a standard type of packaging and then entrust buyers to purchase it at the lowest possible cost. Furthermore, a high percentage of firms used well-established and undifferentiated packaging formats, which had frequently remained unchanged for many years. Packaging became largely a purchasing task. This lead to an orientation towards cost reduction (see Bomsel and Roos, 1990). The selection of suppliers therefore became solely orientated towards the lowest cost. This, in turn, resulted in packaging suppliers having little meaningful involvement in development. Based on these findings we propose: 
Proposition 6: Where packaging buyers ${ }^{5}$ have a high level of influence over packaging decision making this leads to an emphasis on skin deep and body modification changes.

\section{Role and Incorporation of External Capabilities and Consumers}

Theme 7: Role and Incorporation of Packaging Suppliers- FMCG firms' emphasis on the design and communications aspects of packaging is arguably understandable, as they seek to concentrate on their capabilities of developing and marketing the core product. Relationships between the firms and their packaging suppliers were cost-transaction based, in the form of basic procurement. Prior research has shown the significant role played by suppliers in the food chain (e.g. Zuurbier et al., 1996). In the case of packaging suppliers, however, there were limited opportunities for long-term strategic collaboration. Discrepancies in the use of language in particular affected this relationship as interviewees considered 'development' as merely label or aesthetic design changes. Hence they did not foresee the potential for suppliers technical input. We also found that for suppliers the "buyer interface is a big issue [that got] in the way of effective communications" [M33].

Theme 8: Role of Design Agencies- Design agencies and consultancy firms (used by firms R1/R6, P7, P10, P11) frequently offered solutions that were merely graphical (skin deep) or design (body modification) changes (reinforced in interviews with C16, 18, 20, 24, M33, 34). This was dependant on the capabilities of the selected design agency. Firms with an orientation towards format changes displayed a greater awareness of the need to collaborate with suppliers or seek out agencies with greater technical expertise. Whilst firms with a skin deep or body modification orientation frequently overlooked the potential significance of an agencies' capabilities. Packaging suppliers were primarily only consulted for ' 'costings'... once the product has been designed" [C16]. These findings are consistent with existing literature on supplier relationships (Lambert, 2008) and provide novel insights into the impact of skin deep- and body modification change-emphasis on the purchasing relationship with suppliers, which can be characterised as transaction cost in nature (e.g. Wynstra et al., 2010). Hence:

Proposition 7: Firms with an orientation towards format change are more likely to collaborate with suppliers or design agencies, that have technical capability, thus capturing the opportunities from the technologies from the packaging suppliers.

\footnotetext{
${ }^{5}$ Packaging buyers may be either buyers whose specific role it is to purchase packaging, or general buyers within a firm that are given the responsibility for packaging within any particular project.
} 
Theme 9: Role of the consumer- Firms exhibiting a skin deep or body modification orientation tended to "orientate the development processes around the input of the consumer" [P7]. This meant that the packaging supplier's input was minimal. Furthermore, the results of focus groups frequently led managers to be concerned that "consumers are unwilling to accept even small increases in price that may result from packaging change" [P11], and that "existing consumers may react negatively to more radical change" [P7]. Whilst prior research has uncovered that the nature of innovation within process industries can lead to a emphasis on incremental and exploitative innovation (e.g. Benner and Tushman, 2002; Chu et al., 2009), our insights show that in the case of packaging the customer's role further perpetuates this emphasis. This resulted in smaller changes being viewed as more acceptable. Hence:

Proposition 8: An orientation towards skin deep and body modification development will lead to development activities being orientated to the consumer. This will, in turn, perpetuate the emphasis on incremental changes and a failure to exploit opportunities for technical innovations.

In the preceding discussions we have proposed a unique way of viewing the new product and packaging development process. This new conceptual framework moves beyond the traditional dominant activity-based models that characterise existing research within FMCG and provides additional insight into packaging development.

\section{Managerial Implications and Future Research}

\section{Managerial Implications}

Our findings indicate a need for firms to re-examine their development activities to ensure that they are addressing all three levels of NPD packaging development and not just the 'skindeep' aspect of packaging. In particular, the differing understandings attached to the term development may lead to the inadvertent overlooking of opportunities. Specifically, many key decision makers view packaging development as simply changes to label and basic aesthetic design alone.

Packaging development is currently being overlooked (Ahmed et al., 2005). It should be considered, managed, and monitored in a more explicit and sustained manner than is currently the case. For example, Marketing Managers should use the framework to evaluate their NPD processes to ensure that packaging is more fully integrated. This should help to ensure that all packaging opportunities are considered and not overlooked.

Our findings show that managers need to recognise the interrelated activities of packaging development. Practical steps can be taken to improve absorptive capacity. For example, this 
could involve the recruitment of staff with technical packaging capabilities, staff training and putting technological 'champions' into place within the NPD team. Managers need to encourage NPD staff to invest time and effort in developing more meaningful relationships with suppliers, rather than seeing them as low cost suppliers of commodity products. Decision makers need to be vigilant of the influence of design agencies and consumers; ensuring that these inputs are balanced with the suppliers potential technical input.

Finally, this study highlights the need for extensive evaluation of potential partners within the development process. Where design agencies are used marketing managers must evaluate the full range of technical capabilities of these partners to ensure that opportunities for innovation are not missed.

\section{Limitations and Future Research}

This study identifies a need for research in marketing beyond the existing limited view of packaging. As Simms and Trott (2010) have shown, prior research in marketing has primarily focused on packaging at the level of marketing communications (see Table I). Current literature in marketing management fails to capture the complexities of new packaging development. Our findings suggest that the existing models of NPD only address the management of packaging at a superficial level (Francis et al., 2008; McFie, 1994). This literature has not addressed incorporation of technical packaging development activities into the NPD process nor the technical development of new packaging itself. Our framework offers a different theoretical approach, which should be seen as a preliminary attempt at addressing an issue that has significant implications for marketing theory.

Our research has uncovered the role of retailers, buyers and the production line in the FMCG supply chain. Each impacts on the scale and scope of packaging activities within firms. We have also revealed the significance of packaging capabilities within the NPD team. These aforementioned activities merit individual examination in order to provide further insight into their management. The propositions presented within this paper guide the way forward for this future research.

Given the exploratory nature of this study, we suggest that the next step should be to undertake a number of in-depth longitudinal comparative case studies examining NPD projects within both brand owners and own label retailers. This will allow the different parts of the framework to be examined in greater detail, and will provide further understanding of the relationships between the actors involved. Future studies in other industries where packaging is of relevance would also make the results more generalisable. Following this the 
framework could then be tested through a large-scale single or cross industry survey. This would allow the relationships between the factors to be determined and their impact on the emphasis of packaging development to be verified. Caution is necessary with this approach given the differences in what people understand 'packaging development' to be (Proposition $3)$.

\section{Conclusions}

We have characterised the management of packaging within NPD in the FMCG industry and identified three discrete perspectives that build on existing models of NPD. The unique conceptual framework we develop and the typology of packaging penetration provide a contribution to NPD theory. The existing models of product development within FMCG industry adopt an activity-based perspective (e.g. Francis et al., 2008; Francis, 2009; MacFie, 1994; Bigliardi et al. 2010). Furthermore, Francis's (2009) model of new food product development at ASDA, the UK grocer, does not examine the nature of packaging activities being undertaken. It merely provides insights into its positioning within the overall NPD process. Our findings have revealed that for many food and drinks firms packaging development is solely occurring at a skin-deep level, while body modifications and new packaging formats are being overlooked. Our new perspective should help to explicate the lack of a pipeline for new packaging innovations, which the marketing literature has identified as a limitation (Ahmed et al., 2005; Simms \& Trott, 2010).

Finally, this paper reveals the specific nature of packaging activities undertaken by firms and explains how these are integrated into the NPD process. It has uncovered the role played by absorptive capacity in determining the level and extent of packaging technology used by firms. We have also shown that this capacity is determined by the presence of packaging champions and level of packaging technical expertise (e.g. Teece, et al., 1997; Zander and Kogut, 1995; Zott, 2001). Marketing managers should now be able to optimise the use of packaging technology within their products.

\section{References}

Ahmed, A., Ahmed, N. and Salaman, A. (2005), "Critical Issues in Packaged Food Business", British Food Journal, Vol. 107, No. 10, pp. 760-80.

Ahmadi, R., and Wang, R. H. (1999), "Managing development risk in product design processes", Operations Research, Vol. 47, No. 2, pp. 235-246.

Ampuero, O. and Vila, N. (2006), "Consumer Perceptions of Product Packaging”, Journal of Consumer Marketing, Vol. 23, No. 2, pp. 100-12. 
Anselmsson, J. and Johansson, U. (2009), "Third generation of retailer brands - retailer expectations and consumer response", British Food Journal, Vol. 111, No. 7, pp. 717-734.

Balconi, M., Brusconi, S., and Orsenigo, L. (2010), "In defense of the linear model: An essay", Research Policy, Vol. 39, No. 1, pp. 1-13.

Benner, M. and Tushman, M. (2002), "Process Management and Technological Innovation: A Longitudinal Study of the Photography and Paint Industries". The Academy of Management Review, Vol. 28, No. 2, pp. 238-256.

Berkhout, G,, Hartmann, D., and Trott, P. (2011), "The role of entrepreneurship in innovation", International Journal of Entrepreneurship and Innovation Management, Vol. 14, No. 1, pp. 60-78.

Bigliardi, B., Bottani, E., Montanari, R., and Giuseppe, V. (2010), "Successful new product development in the food packaging industry: evidence from a case study", International Journal of Engineering, Science and Technology, Vol. 2, No. 9, pp. 13-24.

Bomsel, O. and Roos, P. (1990), "From commodities to evolutionary materials: Towards new forms of customer-supplier relationships", Resources Policy, Vol. 16, No. 2, pp. 104-114.

Bunduchi, R. and Smart, A.U. (2010), "Process Innovation Costs in Supply Networks: A Synthesis", International Journal of Management Reviews, Vol. 12, No. 4, pp. 365-383.

Chu, C., Li, C. and Lin, D. (2009), "The joint effect of project-level exploratory and exploitative learning in new product development", European Journal of Marketing, Vol. 45, No. 4, pp. 531-550.

Churchill, Jr., Gilbert A., and Lacobucci, D. (2005), Marketing Research: Methodological Foundations, 9th ed., Thomson Learning, Mason, Ohio, OH.

Cohen, W. M. and Levinthal, D. A. (1990), “Absorptive capacity: A new perspective on learning and innovation", Administrative Science Quarterly, Vol. 35, No. 1, pp. 128-152.

Cooper, R.G. (2008), "What leading companies are doing to re-invent their NPD processes", Reprinted from PDMA Visions Magazine, Stage Gate International, Product Development Institute, USA, Reference Paper: 34, pp. 6-10.

Corstjens, J. and Corstjens, M. (1995), Store Wars. John Wiley \& Sons, West Sussex, UK.

Costa, A.I.A., Dekker, D. and Jongen, W.M.F. (2001), “An overview of means-end theory: potential application in consumer-oriented food product design", Trends in Food Science \& Technology, Vol. 15, No. 7-8, pp. 403-415.

Davies, M. and Wright, L.T. (1994), “The importance of labelling examined in food marketing”, European Journal of Marketing, Vol. 28, No. 2, pp. 57-67.

Daymon, C. and Holloway, I. (2002), Qualitative research methods in Public Relations and Marketing Communications, Routledge, London, UK. 
Deliza, R., and H. MacFie, H. (2001), "Product Packaging and Branding", In Frewer, L. J., Risvik, E. and Schifferstein, H. (Eds.), Food, People and Society. A European Perspective of Consumers' Food Choices. Springer, Germany, pp. 55-74.

Denzin, N. K., and Lincoln, Y S. (1994), "Introduction: Entering the field of qualitative research". In Denzin, N. K. and Lincoln, Y. S. (Eds.), Handbook of qualitative research, Thousand Oaks, Sage, California, CA, pp. 1-17.

Deshpande, R (1983), “'Paradigms Lost': On Theory and Method in Research in Marketing”, Journal of Marketing, Vol. 47, No. 4, pp. 101-110.

Ernst \& Young/ACNielsen (1999), Efficient Product Introductions: The Development of Value Creating Relationships, ECR Europe Publication.

Fuller, G.W. Eds. (2004), New Food Product Development: From Concept to Marketplace $2^{\text {nd }}$, CRC Series in Contemporary Food Science, Boca Raton, Florida.

Francis, M. (2009), "Private label new product development process improvement in the UK fast moving consumer goods industry", International Journal of Innovation Management, Vol.13, No.2, pp.467-499.

Francis, M., Dorrington, P. and Hines, P. (2008), "Supplier-led New Product Development Process Improvement in the UK Fast Moving Consumer Goods Industry", International Journal of Innovation Management, Vol. 12, No. 2, pp. 195-222.

Fuller, G.W. (2004), New Food Product Development: From Concept to Marketplace, 2nd. Ed., CRC Press, Boca Raton, Florida.

Goulding, C. (2002), Grounded Theory: A practical Guide for Management, Business and Market Researchers, Sage, London.

Institute of Logistics and Distribution Management (ILDM) (1993), Logistics and the Environment, Corby: ILDM, cited in Prendergast, G. and Pitt L. (1996), “Packaging, Marketing, Logistics and the Environment: Are There Trade-Offs?", International Journal of Physical Distribution and Logistics Management, Vol. 26, No. 6, pp. 60-72.

Isabella, L. A. (1990), "Evolving interpretations as change unfolds: How managers construe key organizational events", Academy of Management Journal, Vol. 33, No. 1, pp. 7-41. Iiori, M.O., Oke, J.S. and Sanni, S.A. (2001), "Management of new product development in selected food companies in Nigeria", Technovation, Vol. 20, No. 6, pp. 333-342.

Key Note (2006), "Food Industry Market Review”, Mintel, UK.

Kleinschmidt, E. J. and Cooper, R. G. (1991), “The impact of product innovativeness on performance", Journal of Product Innovation Management, Vol. 8, No. 4, pp. 240-251.

Koss, J. (2007), “Beverage Packaging Overview”, Beverage World, Vol. 126, No. 9, p. 132.

Keaveney, S. (1995), "Customer switching behaviour in service industries: an exploratory study", Journal of Marketing, Vol. 59, No. 2, pp. 71-82. 
Lager, T. (2000), "A new conceptual model for the development of process technology in Process Industry”, International Journal of Innovation Management, Vol. 4, No. 3, pp. 319-346.

Lambert, D.M. (2008). Supply Chain Management: Processes, Partnerships, Performance, Supply Chain Management Institute, Sarasota, Florida (FL), USA.

LeCompte, M.D. and Goetz, J.P. (1982), "Ethnographic data collection in evaluation research", Educational Evaluation and Policy Analysis, Vol. 4, No. 3, pp. 387-400.

Lee, S.G. and Lye, S.W. (2003), "Design for manual packaging", International Journal of Physical Distribution \& Logistics Management, Vol. 33, No. 2, pp.163 - 189.

Lincoln, Y.S. and Guba, E.G. (1985), Naturalistic Inquiry, Sage, Beverly Hills, California (CA), USA.

MacGregor, A., Parra, I., and Pilar, L. (2006), "Supporting new product creation in the Mondragon Valley", European Journal of Innovation Management, Vol. 9, No. 4, pp. 418-43.

Mahalik N.P. and Nambiara A.N. (2010). "Trends in food packaging and manufacturing systems and technology", Trends in Food Science \& Technology, Vol. 21, No. 3, pp. 117128.

Markham, S. K., and Griffin, A. (1998), "The Breakfast of Champions: Associations Between Champions and Product Development Environments, Practices and Performance", Journal of Product Innovation Management, Vol. 15, No. 5, pp. 436-454.

McCarthy, I. P., Tsinopoulos, C., Allen, P., and Rose-Anderssen, C. (2006), "New Product Development as a Complex Adaptive System of Decisions", Journal of Product Innovation Management, Vol. 23, No. 5, pp. 437-456.

McFie, H. (1994), “Computer Assisted Product Development”, World of Food Ingredients, October/November, pp. 44-9.

Miles, M.B. and Huberman, A.M. (1994), Qualitative Data Analysis: An expanded sourcebook, Sage, Thousand Oaks, California (CA), USA.

Morris, C.E. (1993), "Why New Products Fail”, Food Engineering, Vol. 65, No. 6, p. 129.

Mulhern, F. (1997), "Retail Marketing: from distribution to integration", International Journal of Research in Marketing, Vol. 14, No. 2, pp. 103-124.

Nag, R., Corley, K. G., and Gioia, D. A. (2007), “The intersection of organizational identity, knowledge, and practice: Attempting strategic change via knowledge grafting”. Academy of Management Journal, Vol. 50, No. 4, pp. 821-847.

Nancarrow, C., Wright, L. and Brace, I. (1998), 'Gaining Competitive Advantage from Packaging and Labeling in Marketing Communications', British Food Journal, Vol. 100, No. 2, pp. 110-18.

Neuman, W.L. (2003), Social Research Methods, $5^{\text {th }}$ Ed., Pearson Ed., Boston, MA. 
Oorschot, K. V., Sengupta, K., Akkermans, H., and Van Wassenhove, L. (2010), "Get Fat Fast: Surviving Stage-Gate in New Product Development", Journal of Product Innovation Management, Vol. 27, No. 6, pp. 828-839.

Orth, U. R. and Malkewitz, K. (2008), "Holistic Package Design and Consumer Brand Impressions", Journal of Marketing, Vol. 72, No. 3, pp. 64-81.

Pattikawa, L.H., Verwaal, E. and Commandeur, H.R. (2006), "Understanding new product project performance", European Journal of Marketing, Vol. 40, No. 11/12, pp. 1178-1193.

Richmond, M. (2004), 'The Real Value of Packaging', URL (consulted 10/12/2011): http://pti-solutions.com/resources/articles/.

Rudder, A., Ainsworth, P. and Holgate, D. (2001), "New Food Product Development: Strategies for Success?", British Food Journal, Vol. 103, No. 9, pp. 657-71.

Rudolph, M. (1995), “The Food Product Development Process”, British Food Journal, Vol. 97, No. 3, pp. 3-11.

Rundh, B. (2005), "The Multi-faceted Dimension of Packaging”, British Food Journal, Vol. 107, No. 9, pp. 670-94.

Saghir, M. (2002), "Packaging information needed for evaluation in the supply chain: the case of the Swedish grocery retail industry", Packaging Technology and Science, Vol. 5, No. 1, pp. 37-46.

Silayoi, P. and Speece, M. (2007), "The importance of packaging attributes: a conjoint analysis approach", European Journal of Marketing, Vol. 41, No.11/12, pp.1495 - 1517.

Stewart, B. (1996), Packaging as an Effective Marketing Tool, Kogan Page, London, UK.

Stewart-Knox, B. and Mitchell, P. (2003), "What separates the winners from the loosers in new product development?" Trends in Food Science and Technology, Vol. 14, pp. 58-64.

Strauss, A.L. (1987), Qualitative analysis for social scientists, Cambridge University Press, UK.

Strauss, A.L. and Corbin, J. (1998), Basics of qualitative research, Sage, Newbury Park, California (CA), USA.

Simms, C. and Trott, P. (2010), "Packaging development: A conceptual framework for identifying new product opportunities", Marketing Theory, Vol. 10, No. 4, pp. 397-415.

Swahn, J., Mossberg, L. and Gustafsson, O. (2012), "Sensory description labels for food affect consumer product choice", European Journal of Marketing, Vol. 46, No. 11/12, pp. 1628-1646.

(The) Packaging Federation (2004), Packaging in the 3rd Millennium. Competitiveness Study for the Packaging Industry in the UK, available at: [www.packagingfedn.co.uk/news/] (accessed 12 November 2011).

Teece, D.J., Pisano, G., and Shuen, A. (1997), "Dynamic capabilities and strategic management", Strategic Management Journal, Vol. 18, No. 7, pp. 509-533. 
Troy, L.C., Szymanski, D.M. and Varadarajan, P.R. (2006), “Generating new product ideas: an initial investigation of the role of market information and organizational characteristics", Journal of Academy of Marketing Science, Vol. 29, No. 1, pp. 89-101.

Utterback, J. M., and Abernathy, W. J. (1975), “A dynamic model of process and product innovation”, Omega 3, Vol. 6, pp. 639-656.

Vazquez, D., Bruce, M. and Studd, R. (2003), "A case study exploring the packaging design management process within a UK food retailer", British Food Journal, Vol. 105, No. 9, pp. 602-617.

Vidales Giovannetti, M.D. (1995), El mundo del envase. Manual para el diseno y production de envasesy embalajes, Cited in Ampuero, O. and Vila, N. (2006), "Consumer Perceptions of Product Packaging”, Journal of Consumer Marketing, Vol. 23, No. 2, pp. 100-12.

Wynstra, F., Von Corswant, F. and Wetzels, M. (2010), "In chains? An empirical study of antecedents of supplier product development activity", Journal of Product Innovation Management, Vol. 27, No. 5, pp. 625-639.

Yeoh, P.L. (2009), "Realized and Potential Absorptive Capacity: Understanding Their Antecedents and Performance in the Sourcing Context", The Journal Of Marketing Theory And Practice, Vol. 17, No. 1, pp. 21-36.

Yin, R. (1994), Case study research: Design and methods (2nd ed.), Sage Publishing, Thousand Oaks, California (CA), USA.

Zuurbier, P.J.P. Trienekens, J.H., and Ziggers, G.W. (1996), Vertical Cooperation: Concepts to Start Partnerships in Food and Agribusiness, Elsever, Deventer (in Dutch). 
Table I: Key functions or roles of packaging identified in the literature

\begin{tabular}{|c|c|c|}
\hline Core functions/roles & Elements of packaging's role & Literature \\
\hline Protection & $\begin{array}{l}\text { Effects on the supply chain } \\
\text { Tamperproof } \\
\text { Role in transportation and logistics } \\
\text { Product safety and quality } \\
\text { Preservation/shelf life of the product } \\
\text { Protection from hazards: mechanical; } \\
\text { chemical; environmental; climatic; } \\
\text { bacteriological }\end{array}$ & $\begin{array}{l}\text { The Packaging Federation, } 2004 \\
\text { Stewart, 1996 } \\
\text { Stewart, 1996; Predergast and Pitt, } 1996 \\
\text { Rundh, 2005; Lee et al., 1991; Vidales } \\
\text { Giovanetti, } 1995 \\
\text { Lee et al., 1991, Nancarrow et al., } 1998 \\
\text { \}Lee } \text { et al., } 1991\end{array}$ \\
\hline Containment & $\begin{array}{l}\text { Aids customers use of product } \\
\text { Containing and holding product } \\
\text { Quantity/amount } \\
\text { Facilitating/convenience handling } \\
\text { Affect on quality } \\
\text { Compatibility and constraints }\end{array}$ & $\begin{array}{l}\text { Stewart, 1996 } \\
\text { Stewart, 1996; Lee et al., 1991; Vidales } \\
\text { Giovanetti, 1995; Rundh, 2005 } \\
\text { Nancarrow et al., } 1998 \\
\text { Predergast and Pitt, } 1996 \\
\text { \} Lee } \text { et al., } 1991\end{array}$ \\
\hline Identification & $\begin{array}{l}\text { Product identification } \\
\text { Labelling (effective) } \\
\text { Information: Copy/illustrations on use }\end{array}$ & $\begin{array}{l}\text { The Packaging Federation, 1993; Vidales } \\
\text { Giovanetti, 1995; Nancarrow et al. } 1998 \\
\text { Rundh, 2005; Davies \& Wright, 1994; } \\
\text { Swahn et al., } 2012 \\
\text { Rundh, 2005; Lee } \text { et al., 1991; } \\
\text { Nancarrow et al. } 1998\end{array}$ \\
\hline Marketing communication & $\begin{array}{l}\text { Supporting marketing communications } \\
\text { Supporting promotion of other products } \\
\text { Sales/marketing } \\
\text { Positioning }\end{array}$ & $\begin{array}{l}\text { Institute of Logistics and Distribution } \\
\text { Management, } 1993 \\
\text { Predergast and Pitt, } 1996 \\
\text { Ampuero and Vila, } 2006 \\
\text { Ampuero and Vila, 2006 }\end{array}$ \\
\hline Cost & $\begin{array}{l}\text { Transport and storage costs } \\
\text { Process cost implications }\end{array}$ & $\begin{array}{l}\text { Rundh, 2005; Stewart, } 1996 \\
\text { e.g. Utterbuck and Abernathy }\end{array}$ \\
\hline User convenience & $\begin{array}{l}\text { Openability/access } \\
\text { Reclosability } \\
\text { Carrying } \\
\text { Dispensing facilities } \\
\text { Affecting consumer value } \\
\text { New solutions } \\
\text { Consumer convenience } \\
\text { Suitable quantity/format }\end{array}$ & $\begin{array}{l}\text { \}Lee et al., } 1991 \\
\text { Lee et al., 1991; Nancarrow et al., } 1998 \\
\text { \}Rundh, } 2005 \\
\text { Rundh, 2005; The Packaging Federation, } \\
\text { 2004; Lee et al., } 1991 \\
\text { The Packaging Federation, } 2004\end{array}$ \\
\hline Market appeal & $\begin{array}{l}\text { Consumer and market appeal } \\
\text { Branding } \\
\text { Reinforcing the product concept } \\
\text { Ability to improve sales } \\
\text { Facilitating commercialisation }\end{array}$ & $\begin{array}{l}\text { Lee et al. } 1991 \\
\text { Nancarrow et al., } 1998 \\
\text { Rundh, } 2005 \\
\text { The Packaging Federation, } 2004 \\
\text { Vidales Giovanetti, } 1995\end{array}$ \\
\hline Innovation & Innovation and technology & $\begin{array}{l}\text { Rundh, 2005; Simms and Trott, 2010; } \\
\text { Ahmed et al., } 2005\end{array}$ \\
\hline
\end{tabular}


Table II: Typology of packaging penetration properties within FMCG firms, showing the three levels of change evident within their NPD activities: skin deep, body modification, format change.

\begin{tabular}{|c|c|c|c|c|}
\hline $\begin{array}{l}\text { Level of } \\
\text { packaging } \\
\text { change }\end{array}$ & $\begin{array}{l}\text { Penetration of } \\
\text { packaging change }\end{array}$ & $\begin{array}{l}\text { Absorptive } \\
\text { capacity }\end{array}$ & Technology capability & Evident in firms \\
\hline Skin Deep & $\begin{array}{l}\text { 1. Reprographics } \\
\text { and artwork }\end{array}$ & Low & $\begin{array}{l}\text { Low, little technical or } \\
\text { general packaging } \\
\text { capability } \\
\text { Largely marketing and } \\
\text { reprographics }\end{array}$ & $\begin{array}{l}\mathrm{R} 1 \text { and } 6, \mathrm{R} 3, \mathrm{P} 9, \\
\mathrm{P} 8, \mathrm{P} 11 \\
\text { Also reflected in } \\
\text { orientation of } \\
\text { marketing agencies } \\
\text { when recruited in } \\
\text { development }\end{array}$ \\
\hline $\begin{array}{l}\text { Body } \\
\text { Modification }\end{array}$ & $\begin{array}{l}\text { 2. Plus Design and } \\
\text { aesthetics }\end{array}$ & Limited/medium & $\begin{array}{l}\text { Medium, based on } \\
\text { understanding of non- } \\
\text { technical specialists } \\
\text { Capability largely } \\
\text { graphic and aesthetic } \\
\text { design }\end{array}$ & $\begin{array}{l}\text { P10, R4 } \\
\text { Also evident with } \\
\text { respect to design } \\
\text { agency } \\
\text { collaboration }\end{array}$ \\
\hline $\begin{array}{l}\text { Format Change or } \\
\text { Innovation }\end{array}$ & $\begin{array}{l}\text { 3. Plus format/ } \\
\text { technological } \\
\text { change }\end{array}$ & Extensive & $\begin{array}{l}\text { High, industrial design } \\
\text { and technological } \\
\text { capabilities }\end{array}$ & R5, P12 \\
\hline
\end{tabular}


